\title{
Pengaruh Penggunaan Ampas Kecap dalam Ransum terhadap Isoflavon LDL dan HDL Telur Itik Mojosari
}

\author{
Effect of Soy Sauce by Product Addition in Rations on Isoflavones LDL and HDL of Mojosari \\ Duck Eggs
}

H. Saputro, L. D. Mahfudz, dan T. A. Sarjana

Fakultas Peternakan dan Pertanian, Universitas Diponegoro, Semarang

Email : Handras.saputra64@gmail.com

\begin{abstract}
This study was aimed to examine the use of soy sauce by product in the rations on LDL (Low Density Lipoprotein), HDL (High density lipoprotein) and Isoflavon of egg of Mojosari duck. The material used where 240 Mojosari duck atof 24 weeks old with an initial body weight of 1,385.0 \pm 130.8 grams $(C V=9.44 \%)$. Feed ingredients used where yellow corn, bran, soybean meal, fish meal, pollard, premix and soy sauce by product. The experimental design used was Completely Randomized Design (CRD) with 4 treatments and 6 replications so that there were 24 experimental units. The treatment of soybean souce by product pulp in the rations as follows T0: 0\%, T1: 5\%, T2: 7.5\% and T3: 10\%. The observed parameters were Isoflavone LDL and HDL of egg yolks. The data obtained were analyzed using analysis of variance (anova) with $\mathrm{F}$ test at $5 \%$ then continued Duncan double area test. The results showed that the soy sauce by product increased $(\mathrm{P}<0.05)$ the levels of Isoflavone and HDL, but has LDL of egg yolk. The conclusion of this research is the use of soy sauce by product in ration until level $10 \%$ can improve chemical.quality of egg.
\end{abstract}

Key words: laying ducks, soy sauce by product, LDL, HDL, Isoflavones.

\begin{abstract}
ABSTRAK
Penelitian ini bertujuan untuk mengkaji penggunaan ampas kecap dalam ransum terhadap LDL (Low Density Lipoprotein), HDL (High density lipoprotein)dan Isoflavontelur itik mojosari. Materi yang digunakan adalah 240 ekor itik Mojosari petelur umur 24 minggu dengan rata - rata bobot badan awal 1.385,0 $\pm 130,8$ gram $(\mathrm{CV}=$ $9,44 \%)$. Bahan pakan yang di gunakan adalah jagung kuning, bekatul, bungkil kedelai, tepung ikan, pollard, premix dan ampas kecap. Rancangan percobaan yang digunakan adalah Rancangan Acak Lengkap (RAL) dengan 4 perlakuan dan 6 ulangan sehingga terdapat 24 unit percobaan. Perlakuan ampas kecap ke dalam ransum adalah sebagai berikut $\mathrm{T} 0: 0 \%, \mathrm{~T} 1: 5 \%, \mathrm{~T} 2: 7,5 \%$ dan $\mathrm{T} 3: 10 \%$. Parameter yang di amati adalah Isoflavon LDL dan HDL kuning telur. Data yang diperoleh dianalisis menggunakan analisis ragam pada taraf 5\% kemudian dilanjutkan uji wilayah ganda Duncan. Hasil penelitian menunjukkan bahwa ampas kecapnyata meningkatkan $(\mathrm{P}<0,05)$ kadar Isoflavon LDL dan HDL kuning telur itik. Kesimpulan dari penelitian ini adalah penggunaan ampas kecap dalam ransum sampai level 10\% dapat meningkatkan kualitas kimiawitelur.
\end{abstract}

Kata kunci : itik petelur, ampas kecap, LDL, HDL, Isoflavon.

\section{PENDAHULUAN}

Indonesia merupakan salah satu negara yang memiliki populasi itik terbesar di dunia. Telur itik merupakan makanan yang sangat di gemari di berbagai seluruh wilayah di Indonesia karena harga yang relatif murah dan juga telur itik mengandung protein, lemak, kolesterol, mineral dan vitamin yang lebih tinggi dibanding telur unggas lain. Namun semakin maraknya isu mengenai telur sebagai salah satu sumber lemak dan kolesterol menjadikan telur itik semakin ditakuti untuk dikonsumsi. Sehingga perlu adanya upaya untuk menurunkan kadar lemak dan kolesterol dalam telur itik. Sacher dan McPherson (2004) mengemukakan bahwa kolesterol terdapat di dalam darah bersama dengan trigliserida, fosfolipid, dan apoprotein membentuk lipoprotein. 2 Lipoprotein di dalam darah, yaitu kilomikron, very low density lipoprotein (VLDL), low density lipoprotein (LDL), dan High density lipoprotein (HDL). Kadar kolesterol dapat 
dipengaruhi oleh pakan yang dikonsumsi dan genetik. Maka perlu upaya menjadikan produk ternak yang rendah kolesterol. Dalam usaha peternakan unggas pakan adalah biaya produksi paling tinggi $(70-80 \%)$. Perlu dicarikan bahan pakan alternative untuk menurunkan kadar lemak dan kolesterol yaitu menggunakan penambahan bahan pakan ampas kecap.

Ampas kecap merupakan suatu limbah dalam bentuk padat hasil penyaringan dan pengepresan dari proses pembuatan kecap. Menurut Sitorus (1986) menyatakan bahwa ampas kecap merupakan hasil dari limbah proses pembuatan kecap yang berbahan kedelai dan memiliki kandungan protein yang cukup tinggi dan palatable. Ampas kecap memiliki massa seperti gel dan berwarna coklat sampai hitam.Ampas kecap memiliki kandungan nutrien yang baik terutama kandungan protein yang mencapai 20-27\% (Sukarini, 2003) sehingga dapat digunakan sebagai campuran bahan pakan itik.

Widayati dan Widalestari (1996) melaporkan bahwa ampas kecap mengandung protein $24,90 \%$, kalsium $0,39 \%$, dan fosfor $0,33 \%$. selain memiliki kandungan nutrisi yang tinggi ampas kecap juga memiliki kandungan terdapat senyawa isoflavon. Isoflavon sendiri adalah mampu mengatasi adanya stress oksidan. Mekanisme ampas kecap dalam menurunkan kolesterol telur yaitu ampas kecap mengandung zat aktif isoflavon yang merupakan antioksidan dan sterol yang berasal dari tumbuhan (fitoestrol), apabila dikonsumsi itik, maka akan menghambat penyerapan kolesterol jahat yang berasal dari pakan maupun dari dalam tubuh (hati). Hal ini dapat terjadi karena fitoesterol berkompetisi dengan kolesterol dan menggantikan kolesterol didalam micelle, maka penyerapan kolesterol di dalam usus dapat berkurang, sehingga kolesterol yang di deposisikan ke dalam sel telur menjadi sedikit.

Isoflavon adalah senyawa aditif yang potensial dalam meningkatkan produktivitas dan kualitas produksi unggas petelur. Bioaktivitas fungsi biologis senyawa isoflavon mempunyai peranan terhadap dua hal penting yaitu sebagai antioksidan dan berperan pada aspek kesehatan ternak. Isoflavon mempunyai potensi sebagai antioksidan didasarkan pada kemampuan mendonasikan hydrogen dalam menangkap radikal bebas. Sedangkan isoflavon pada aspek kesehatan didasarkan pada kesamaan struktur dan fungsi biologis dengan phytoestrogen.

Fitoestrogen adalah senyawa isoflavon yang mirip dengan estrogen dalam struktur dan aktivitas biologis. Aktivitas estrogenik isoflavon terkait dengan struktur kimianya yang mirip dengan stilbestrol, yang biasa digunakan sebagai obat estrogenik. Isoflavon dari kedelai fermentasi dapat meningkatkan komponen fungsional, seperti peningkatan aglikon isoflavon dan peptida aktif yang memiliki lebih manfaat kesehatan (Hong et al, 2011 ; Mejia and Lumen, 2006). Perubahan ini disebabkan pada proses perendaman dan fermentasi dapat mengaktifkan enzim $\beta$ - glukosidase baik dari kedelai maupun dari kapang, dimana enzim ini akan menghidrolisis glikosida isoflavon menjadi aglikon isoflavon (Pawiroharsono, 1997).

Penelitian lain mengenai ampas kecap dalam ayam petelur 80/100 mg dapat menurunkan rasio LDL dan meningkatkan HDL oksidan SOD darah ayam (Malik et al, 2015). Peneliti Sukarini et al. (2004) mengenai pemberian ampas kecap fermentasi sampai level $12,5 \%$ pada ayam broiler, berpengaruh nyata menurunkan kadar lemak daging dan meningkatkan kandungan protein daging. Kandungan zat aktif isoflavon pada kedelai, diketahui dapat menurunkan kadar kolesterol serum tikus (secara in vitro) (Nisa et al., 2007). Peneliti berminat meneruskan penelitian ampas kecap terhadap kandungan Isoflavon, LDL dan HDL kuning telur itik. Tujuan dari penelitian ini adalah untuk menurunkan kadar LDL dan meningkatkan kadar HDL dengan Isoflavon ampas kecap di dalam ransum terhadap kuning telur itik Mojosari. 


\section{BAHAN DAN METODE}

Penelitian ini dilaksanakan pada bulan 28 November 2016 - 28 Januari 2017 di Kandang Penelitian Universitas Darul Islam, Ungaran, Semarang dengan menggunakan itik Mojosari (Anas platyrnchos) sebanyak 240 ekor dengan umur 20 minggu dengan berat badan awal rata rata 1424,61 $\pm 27,09$ gram. Ampas kecap yang digunakan diperoleh dari limbah perusahaan kecap "Lele" di Pati. Bahan penyusun ransum meliputi dedak padi, jagung kuning, bungkil kedelai, tepung ikan, pollard, premix dan ampas kecap.

Kandungan nutrisi bahan pakan dapat dilihat pada Tabel 1. Komposisi kandungan nutrisi ransum ada pada Tabel 2. Perlakuan yang diberikan yaitu berupa tingkat penggunaan ampas kecap dalam ransum yaitu $0 \%, 5 \%, 7,5 \%$ dan $10 \%$ (Tabel 2).

Tabel 1. Kandungan nutrisi bahan pakan

\begin{tabular}{|c|c|c|c|c|c|c|}
\hline \multirow[b]{2}{*}{ Bahan Pakan } & \multicolumn{6}{|c|}{ Kandungan nutrisi } \\
\hline & $\begin{array}{l}\mathrm{EM} \\
(\mathrm{Kkal} / \mathrm{kg})\end{array}$ & PK & LK & SK & $\mathrm{Ca}$ & $\mathrm{P}$ \\
\hline Ampas Kecap & $3.924,14^{\mathrm{c}}$ & $28,78^{\mathrm{a}}$ & $1,84^{\mathrm{a}}$ & $46,17^{a}$ & $1,70^{\mathrm{a}}$ & $0,70^{\mathrm{a}}$ \\
\hline Jagung Kuning & $2.785,32^{c}$ & $9,40^{\mathrm{a}}$ & $4,22^{\mathrm{a}}$ & $2,44^{\mathrm{a}}$ & $0,03^{\mathrm{b}}$ & $0,23^{\mathrm{b}}$ \\
\hline Tepung Ikan & $2.091,40^{\mathrm{c}}$ & $38,55^{\mathrm{a}}$ & $5,18^{\mathrm{a}}$ & $2,31^{\mathrm{a}}$ & $12,08^{\mathrm{b}}$ & $3,05^{\mathrm{b}}$ \\
\hline Bekatul & $3.395,00^{\mathrm{c}}$ & $12,06^{\mathrm{a}}$ & $13,58^{\mathrm{a}}$ & $8,39^{\mathrm{a}}$ & $0,32^{b}$ & $1,70^{\mathrm{b}}$ \\
\hline Pollard & $2.587,10^{\mathrm{c}}$ & $13,46^{\mathrm{a}}$ & $0,70^{\mathrm{a}}$ & $4,48^{\mathrm{a}}$ & $0,09^{\mathrm{b}}$ & $0,78^{\mathrm{b}}$ \\
\hline Bungkil kedelai & $2.985,05^{\mathrm{c}}$ & $42,84^{\mathrm{a}}$ & $3,00^{\mathrm{a}}$ & $1,90^{\mathrm{a}}$ & $0,24^{\mathrm{b}}$ & $0,57^{\mathrm{b}}$ \\
\hline Premix & $959,430^{c}$ & $5,26^{\mathrm{a}}$ & $4,23^{\mathrm{a}}$ & $3,35^{\mathrm{a}}$ & $3,30^{\mathrm{a}}$ & $3,50^{\mathrm{a}}$ \\
\hline
\end{tabular}

Sumber : a) Hasil Analisis Proksimat Laboratorium Ilmu Nutrisi dan Pakan,UNDIP, 2016.

b) Hartadi et al, 1997. c) Hasil Perhitungan energi berdasarkan rumus Balton (Siswohardjono, 1982)

$\mathrm{EM}=40,81(0,87($ Protein kasar + 2,25 Lemak kasar + BETN $)+2,5)$.

Tabel 2. Komposisi dan kandungan nutrisi ransum perlakuan

\begin{tabular}{lrrrr}
\hline Bahan Pakan & T0 $(0 \%)$ & T1 $(5 \%)$ & T2 $(7,5 \%)$ & T3 (10\%) \\
\hline Jagung Kuning & 41,70 & 40,60 & 41,00 & 39,70 \\
Bekatul & 26,20 & 20,00 & 16,50 & 13,70 \\
Bungkil Kedelai & 17,60 & 14,70 & 13,50 & 12,00 \\
Tepung Ikan & 7,00 & 7,20 & 7,00 & 7,10 \\
Pollard & 6,50 & 11,50 & 13,50 & 16,50 \\
Premix & 1,00 & 1,00 & 1,00 & 1,00 \\
Ampas Kecap & 0,00 & 5,00 & 7,50 & 10,00 \\
\hline Total & 100,00 & 100,00 & 100,00 & 100,00 \\
\hline Kandungan Nutrisi : & \multicolumn{3}{c}{} & \\
\hline Protein Kasar $(\%)$ & 18,07 & 18,09 & 18,08 & 18,10 \\
Lemak Kasar $(\%)$ & 6,30 & 5,46 & 5,01 & 4,61 \\
Serat Kasar $(\%)$ & 4,04 & 5,97 & 6,91 & 7,90 \\
Kalsium $(\%)$ & 1,02 & 1,11 & 1,12 & 1,16 \\
Fosfor $(\%)$ & 0,94 & 0,90 & 0,86 & 0,84 \\
EM (kkal/kg) & $2.900,00$ & $2.903,00$ & $2.905,00$ & $2.906,00$ \\
\hline
\end{tabular}

Parameter yang diamati dalam LDL dan HDL kuning telur. Rancangan penelitian ini yaitu kandungan Isolfavon, percobaan yang akan digunakan dalam 
penelitian ini adalah Rancangan Acak lengkap (RAL), dengan 4 perlakuan dan 6 ulangan sehingga ada 24 unit percobaan, dimana setiap unit ada 10 ekor itik petelur. Data yang diperoleh dianalisis dengan menggunakan analisis ragam atau Analisis of Variance (Anova) dan uji $\mathrm{F}$ pada taraf 5\%. Jiak terdapat pengaruh perlakuan, dilanjutkan dengan uji jarak berganda Duncan untuk mengetahui pengaruh perbedaan antara nilai tengah perlakuan.

\section{HASIL DAN PEMBAHASAN}

Hasil penelitian menunjukan bahwa rata-rata HDL, LDL dan Isoflavon pada kuning telur itik mojosari dengan perlakuan penggunaan ampas kecap dapat dilihat pada tabel 3 .

Tabel 3. Rata rata HDL, LDL dan Isoflavon pada kuning telur itik mojosari

\begin{tabular}{lcccc}
\hline Parameter & T0 & T1 & T2 & T3 \\
\hline Isoflavon, & $0,159 \mathrm{~b}$ & $0,294 \mathrm{a}$ & $0,259 \mathrm{a}$ & $0,272 \mathrm{a}$ \\
$\mathrm{mg} / \mathrm{g}$ & & & & \\
LDL, mg/dl & $5,09^{\mathrm{ab}}$ & $6,90^{\mathrm{a}}$ & $5,85^{\mathrm{ab}}$ & $3,59^{\mathrm{b}}$ \\
HDL, mg/dl & $31,90^{\mathrm{b}}$ & $132,05^{\mathrm{a}}$ & $93,66^{\mathrm{a}}$ & $93,39^{\mathrm{a}}$ \\
\hline
\end{tabular}

Superskrip yang berbeda pada baris yang sama menunjukkan perbedaan yang nyata $(\mathrm{P}<0,05)$

\section{Isoflavon}

Hasil analisis menunjukkan bahwa penggunaan ampas kecap dalam ransum berpengaruh nyata $(\mathrm{P}<0,05)$ terhadap kadar isoflavon pada kuning telur. Rataan isoflavon pada masing perlakuan berkisar antara 0,159$0,294 \mathrm{mg} / \mathrm{g}$, dimana rataan tertinggi terdapat pada perlakuan $\mathrm{T} 1$ sebesar $0,294 \mathrm{mg} / \mathrm{g}$ dan terendah pada perlakuan T0 sebesar0,159 $\mathrm{mg} / \mathrm{g}$. Kadar isoflavon yang lebih tinggi pada perlakuan T1,T2 dan T3 dibandingkan dengan T0 dikarenakan oleh adanya penggunaan ampas kecap dalam ransum perlakuan, sehingga menyebabkan isoflavon yang terkandung dalam ampas kecap tercerna dalam tubuh itik dan terdeposisi dalam kuning telur. Juliambarwati et al. (2012) menyatakan bahwa faktor utama yang mempengaruhi kandungan gizi telur itik adalah kualitas dan kuantitas nutrisi rasum, suhu lingkungan, genetik, umur dan bobot badan. Menurut Jayanti (2017), isoflavon merupakan senyawa aditif yang terkandung dalam kedelai dan berperan positif dalam meningkatkan produktivitas dan kualitas telur.

\section{LDL}

Hasil analisis menunjukkan bahwa perlakuan berpengaruh nyata $(\mathrm{P}<0,05)$ terhadap kandungan LDL pada kuning telur. Rata rata kandungan LDL pada masing masing perlakuan berkisar antara 3,59-6,90 $\mathrm{mg} / \mathrm{dl}$, dimana kandungan LDL terendah terdapat pada perlakuan T3 sebesar 3,59 $\mathrm{mg} / \mathrm{dl}$ dan tertinggi pada perlakuan $\mathrm{T} 1$ sebesar $6,90 \mathrm{mg} / \mathrm{dl}$. Kandungan LDL yang rendah pada perlakuan T3 dikarenakan adanya kandungan isoflavon pada ampas kecap, sehingga senyawa isoflavon dapat menghambat absorbsi dari kolesterol yang menyebabkan pembentukan VLDL terhambat dan menurunkan kadar LDL. Menurut Silalahi, (2000), isoflavon merupakan sterol yang berasal dari tumbuhan (fitosterol) yang jika dikonsumsi dapat menghambat absorbsi dari kolesterol,fitosterol ini berkompetisi dan menggantikan posisi kolesterol dalam micelle, dimanaadanya mekanisme tersebut, maka kolesterol yang terserap oleh usus menjadi berkurang sehingga pembentukan kilomikron dan VLDLterhambat sehingga kadar LDL turun.

Yuwanta (2000) menyatakan bahwa LDL yang terdapat pada kuning telur juga dibentuk di dalam hati, yang berasal dari hidrolisis IDL (intermediate density lipoprotein) oleh enzim lipoprotein lipase menjadi LDL, kemudian di alirkan oleh darah menuju oocyt pada ovarium. Semakin rendah rasio kolesterol LDL semakin baik dalam arti resiko untuk mengalami penyakit akibat kolesterol semakinkecil (Mayes, 1999). Heriyani (2016) menyatakan bahwa pemberian pakan yang mengandung flavonoid pada tikus putih mampu menurunkam kandungan kolesterol total dan diikuti dengan penurunan LDL. Malik et al. (2017) menyatakan bahwa isoflavon pada ampas kecap dapat menurunkan kadar LDL 
pada darah ayam petelur. Penggunaan ampas kecap pada taraf $10 \%$ dengan demikian sangat baik untuk menurunkan kadar LDL pada kuning telur.

\section{HDL}

Hasil analisis menunjukkan bahwa perlakuan berpengaruh nyata $(\mathrm{P}<0,05)$ terhadap kandungan HDL pada kuning telur. Rata rata kandungan HDL pada masing masing perlakuan berkisar antara 31,90$132,05 \mathrm{mg} / \mathrm{dl}$, dimana kandungan HDL tertinggi terdapat pada perlakuan T1 sebesar $132,05 \mathrm{mg} / \mathrm{dl}$ dan terendah pada perlakuan T0 sebesar 31,90 mg/dl. Adanya peningkatan kandungan HDL kuning telur pada perlakuan ransum yang menggunakan ampas kecap di karenakan oleh adanya kandungan isoflavon pada ampas kecap terserap dalam tubuh itik, sehingga dapat meningkatkan kadar HDL.

Silalahi (2000) menyatakn bahwa senyawa isoflavon termasuk senyawa estrogeneik dan juga berfungsi untuk katabolisme lemak, dimana senyawa tersebut dapat meningkatkan kadar HDL. Adanya mekanisme tersebut, maka kolesterol yang terserap oleh usus menjadi berkurang sehingga pembentukankilomikron dan VLDLterhambat sehingga kadar LDL turun dan peningkatan pada kadar HDL.

HDL yang tinggi tidak menyebabkan masalah, karena semakin tinggi kadar HDL maka akan menurunkan factor resiko aterogenetik (Sitepoe, 1982). Menurut Chen dan Wei (2008) bahwa komponen isoflavon yang bersal dari kedelai fermentasi, lebih mudah diabsorbsi tubuh daripada komponen isoflavon yang berasal dari kedelai non fermentasi. Isoflavon mampu berikatan dengan reseptor estrogen, sehingga dapat membatu fungsi estrogen dalam meningkatan HDL dengan cara meningkatkan produksi apoliporotein melalui peningkatan aktifitas enzim lipase hepatik dan metabolisme HDL. Malik et al, (2017) menyatakan bahwa kandungan isoflavon pada ampas kecap dapat meningkatkan kandungan HDL pada darah ayam petelur.

\section{KESIMPULAN}

Keimpulan penelitian adalah penggunaan ampas kecap dalam ransum itik Mojosari petelur dapat meningkatkan kandungan HDL dan serta menurunkan LDL kuning telur, sehingga dapat menjadi bahan pangan fungsional.

\section{DAFTAR PUSTAKA}

Hartadi H., S. Reksohadiprojo dan A. D. Tilman. 1997. Tabel Komposisi Pakan Untuk Indonesia. Cetakan Keempat, Gadjah Mada Univesity Press, Yogyakarta.

Heryani, R. 2016. Pengaruh ekstrak buah naga merah terhadap profil lipid darah tikus putih hiperlipidemia. Jurnal Ipteks Terapan. 10(1): 9-17.

Jayanti, R. D., L. D. Mahfudz, dan S. Kismiati. 2017. Pengaruh penggunaan ampas kecap dalam ransum terhadap kadar protein, lemak dan kalsium kuning telur Itik Mojosari. Jurnal Peternakan Indonesia. 19 (3): 122-129.

Juliambarwati, M., A. Ratriyanto dan A. Hanifa. 2012. Pengaruh penggunaan tepung limbah udang dalam ransum terhadap kualitas telur itik. Jurnal Sains Peternakan. 10(1) : $1-6$.

Malik, A., E. Suprijatna., V. D. Yunianto dan L. Djauhari. 2015. Pengaruh isoflavon ampas kecap terhadap antioksidan dan rasio kolesterol LDL/HDL ayam petelur. Prosiding Seminar Nasional Penelitian dan Pengabdian LPPM Universitas Muhamadiyah Purwokerto. 26 September 2015. Aula UMP, Purwokerto. $252-258$.

Mayes, P.A. 1999. Pengangkutan dan penyimpanan lipid. In (Murray RK, Ganner DK, Mayes PA. Rodwell VW). Bokimia Harper edisi 24. Lange EGC: 260-276. 
Mejia, E and B.O. Lumen. 2006. Soybean bioactive peptides: A new horizon in preventing chronic diseases Sexuality. Reproduction and Menopause, 4 (2) : 91-95.

Nisa, F. Z., Y. Marsono, dan E. Harmayani. 2007. Hipokolesterolemik susu kedelai fermentasi steril secara in vitro. Berita Kedokteran Masyarakat 23 (2): 47-51.

Pawiroharsono, S. 1997. Metabolisme isoflavon dan faktor ii $(6,7,4$ trihidroksi isoflavon) pada proses pembuatan tempe. Simposium Nasional Pengembangan Tempe dalam Industri Pangan Modern. Yogyakarta. 15 - 16 : $165-175$.

Rong Chen, T., \& King Wei, Q. 2008. Analysis of bioactive aglycone isoflavones in soybean and soybean products. Nutrition \& Food Science; 38(6): 540-547.

Sacher, R.A., McPherson, R. A. 2004. Tinjauan klinis hasil pemeriksaan laboratorium. edisi 11. Penerbit Buku Kedokteran: ECG, Jakarta,

Sukarini, N. E., L. D. Mahfudz dan A. M. Legowo. 2004. Studi penggunaan ampas kecap yang diproses dengan larutan asam asetat untuk pakan terhadap komposisi kimia dan karakteristik fisik daging ayam broiler.
J. Indonesia Tropis Animal Agriculture. 29(3):129-135.

Silalahi, J. 2000. Fats, oils and fat substitutes in human nutrition. Indonesian Food and Nutrition Process. 7(2): 56-66.

Sitepoe, M. 1992. Kolesterol Fobia. Gramedia Pustaka Utama, Jakarta.

Sitorus, S. 1986. Pemberian urea dan ampas kecap pada domba yang di beri makan jerami padi dan molase. Balai penelitian ternak. Bogor

Sukarini, N. E. 2003. Studi penggunaan ampas kecap yang diproses dengan larutan asam asetat untuk pakan terhadap komposisi kimia dan karakteristik fisik daging ayam broiler. Tesis. Fakultas Peternakan, Universitas Diponegoro. Semarang.

Widayati, E. dan Y. Widalestari. 1996. Limbah untuk pakan ternak. Trubus Agrisarana. Surabaya.

Yang, H., G. Jin, D. Ren, S. Luo, and T. Zhou. 2011. Mechanism of isoflavone aglycone's effect on cognitive performance of senescence-accelerated mice. Brain and cognition.76(1): 206210.

Yuwanta, T. 2000. Dasar Ternak Unggas. Kanisius. Yogyakarta. 